\title{
4: $144792221-144832172$
}

National Cancer Institute

\section{Source}

National Cancer Institute. 4:144792221-144832172. NCI Thesaurus. Code C45107.

Physical location of SMARCA5_Gene 